\title{
The Performance of Chenin blanc Grafted onto Different Rootstock Cultivars on a Dundee Soil in the Montagu District
}

\author{
J.M. Southey and G.W. Fouché
}

Viticultural and Oenological Research Institute (VORI), Private Bag X5026, 7600 Stellenbosch, Republic of South Africa.

Submitted for publication: December 1989

Accepted for publication: April 1990

Key words: Grapevine, rootstock, performance

\begin{abstract}
The performance of Chenin blanc grafted onto 15 different rootstock cultivars and clones, established on a sandy alluvial soil in the Montagu district, was investigated. Over the eleven years of the trial, the highest mean yields were obtained with 99 Richter (Clone: RY 13), Constantia Metallica, Dog Ridge, Ramsey and 101-14 Mgt. The mean yield of 99 Richter (Clone: RY 13) was significantly higher than that of the other 99 Richter clones and selections. The highest pruning masses were found with 143-B Mgt, Dog Ridge, Constantia Metallica and Ramsey. The crop-to-pruning-mass ratio of 143-B Mgt was, however, lower than that of the other graft combinations, which suggests that this graft combination was undercropped and that potentially higher yields could have been obtained. Moderate growth was obtained with the cultivars 101-14 Mgt and 3306 Coucerc. These cultivars showed potential as growth-limiting cultivars as they consistently produced relatively high yields with satisfactory grape composition, associated with low pruning masses.
\end{abstract}

The grafting of Vitis vinifera L. cultivars onto various rootstocks is recommended in all the viticultural regions of the Western Cape, owing to the presence of the grapevine phylloxera (Daktulosphaera vitifoliae Fitch) and various nematode species in the soils. These viticultural regions are characterised by a wide diversity of soil types and climatic factors. Consequently cultivation practices and rootstock preferences also differ within the different regions (Zeeman, 1978), which implies that a wide diversity of rootstock cultivars is necessary.

At present no rootstock cultivar is equally well adapted to the wide range of conditions found in the viticultural regions of South Africa. Although a large number of rootstock cultivars are available in South Africa, only three, namely 99 Richter, 101-14 Mgt and Ramsey, are extensively used and contribute to $77 \%$ of all grafted commercial plantings (Kriel, 1985). For example, 99 Richter is well adapted to a wide variety of soil types but highly susceptible to infection by the soilborne pathogenic fungus Phytophthora cinnamomi P. (Marais, 1978; Loubser, Ferreira \& De Klerk, 1987). Furthermore, 101-14 Mgt has poor affinity with certain scion cultivars, and the growth of Ramsey is often too vigorous and it is difficult to graft (Pongracz, 1983).

Approximately 3350 hectares are currently under grapevines in the Montagu district (Anon., 1988), the majority of the vineyards being planted on Dundee and Hutton soil types, with a smaller percentage on Longlands, Oakleaf, Shortlands and Mispah soil types (McVicar et al., 1977). This district is characterised by a relatively low annual rain- fall (350mm) and high summer temperatures (Mean temperature throughout the growing season $=20,2^{\circ} \mathrm{C}$ ) and can be classified as being in region IV (Winkler et al., 1974; Le Roux, 1974).

In the past, the majority of the winegrapes in this area were either ungrafted, or grafted onto Jacquez, Rupestris du Lot, 143-B Mgt and 101-14 Mgt (Pongracz, 1969; Beukmann 1976). Statistics indicate however, that the popularity of the first three cultivars has declined, whereas that of 101-14 Mgt has increased (Anon., 1988). According to Ambrosi et al., (1966), 101-14 Mgt performed best on the relatively deep, brackish, sandy-loam soils found in this area, whereas 99 Richter was not very popular owing to instances where grapevines grafted onto this rootstock suddenly died. The latter problem was subsequently found to be the result of infection by the pathogenic fungus Phytophthora cinnamomi.

Generally, the predominant problems facing the winegrape producer in this area are the re-establishment of old vineyards, relatively saline soils and an insufficient supply of water for irrigation. The aim of this trial was, therefore, to establish which rootstock cultivars perform best on an alluvial soil type in the Montagu district, thus presenting the producer with a broader rootstock choice.

\section{MATERIALS AND METHODS}

The trial was established during 1974 using a randomized block design with four replicates and 10 vines per plot. Chenin blanc was used as the scion cultivar and was grafted 
onto 15 rootstock cultivars or clones (Table 1). Of these rootstocks, 99 Richter, 101-14 Mgt, Ramsey, 110 Richter and 143-B Mgt were found to be free of known virus diseases.

TABLE 1

Rootstocks included in the field trial at Montagu.

\begin{tabular}{|c|c|}
\hline CULTIVAR (Clone) & GENETIC ORIGIN \\
\hline 101-14 Mgt (KWV) & $V$. riparia Mich. $\mathrm{x} V$. rupestris Sch. \\
\hline 101-14 Mgt (VORI) & $V$.riparia $\mathrm{x} V$.rupestris \\
\hline De Waal & $V$. labrusca Mich. $\mathrm{x} V$. vinifera $\mathrm{L}$. \\
\hline 110 Richter & V. Berlandieri Pl. x V.rupestris Sch. \\
\hline Jacquez & $\begin{array}{l}V . \text { aestivalis Mich. } \mathrm{x} V \text {. cinerea } \text { Engel } \\
\times \text { V } \text {. vinifera } \mathrm{L} .\end{array}$ \\
\hline 143-B Mgt & $V$. rupestris $\mathrm{x} V$.riparia \\
\hline Constantia Metallica & V.rupestris \\
\hline 3306 Couderc & $V$.riparia $\mathrm{x} V$.rupestris \\
\hline Dog Ridge & V. Champini Planch. \\
\hline Ramsey & V. Champini \\
\hline Rupestris du Lot & V.rupestris \\
\hline 99 Richter (RY 13) & $V$. Berlandieri $\times$ V.rupestris \\
\hline 99 Richter (RY 30) & V.Berlandieri $\times$ V.rupestris \\
\hline 99 Richter $(2 / 2 / 10)$ & $V$. Berlandieri $\mathrm{x} V$.rupestris \\
\hline 99 Richter (VORI) & $V$. Berlandieri $\mathrm{x} V$.rupestris \\
\hline
\end{tabular}

The soil of the experimental plot is classified as a Dundee soil type according to the system of McVicar et al, 1977. It can be described as a sandy, alluvial soil, typical of approximately $45 \%$ of the irrigated vineyard soils in the Montagu district when the trial was established. The vines were spaced $2,4 \mathrm{~m} \times 1,2 \mathrm{~m}$ and were trained onto a $1,5 \mathrm{~m}$ slanting trellis. Initially, during the establishment of the trial, the vines were flood-irrigated, but owing to the scarcity of irrigation water a permanent drip irrigation system was installed before the collection of data commenced.

At the start of the trial the vines were spur pruned to a budload of 15 nodes $/ \mathrm{kg}$ pruning mass. With the availability of more irrigation water of a better quality during 1982, however, this pruning norm was found to be unsatisfactory and was adjusted to 30 nodes $/ \mathrm{kg}$ pruning mass, which subsequently appeared to be too high. Consequently, from 1984 onwards, a pruning norm of 25 nodes/kg pruning mass was maintained.

Yield, fruit composition and pruning-mass data were recorded annually and analysed by analysis of variance and orthogonal comparisons. During 1988, the soil was sampled and analysed for the presence of soil-borne pests and diseases, using the methods described by De Klerk $(1970,1978)$, Marais (1983) and Loubser (1985).

\section{RESULTS AND DISCUSSION}

When assessing rootstock performance, the main criterion is a consistent production of relatively high yields of grapes of satisfactory grape composition, coupled with adequate growth over the economic lifespan of the grapevine. In this trial both the rootstock cultivar and the clone showed marked effects on the performance of Chenin blanc. The results are given in Table 2.

Yield: The highest mean yields were obtained with Chenin blanc grafted onto 99 Richter (Clone: RY 13), Constantia Metallica, Dog Ridge, Ramsey and 101-14 Mgt, all of which produced more than $25 \mathrm{t} / \mathrm{ha}$ and did not differ significantly, whereas De Waal produced the poorest mean yield (Table 2).

The annual fluctuation in the yield of the graft combinations could be the consequence of seasonal trends or climatic conditions. The yields of the graft combinations increased from 1982 relative to the preceding years (Fig. 1). At this stage more irrigation water of a higher quality was available and the resulting increase in the growth of the vines, measured as pruning mass, prompted an adjustment in the budload, which was then raised to approximately 30 nodes per kg pruning mass. This was found to be too high, however, as indicated by the high crop:pruning mass ratios (Mean for

TABLE 2

The mean performance of Chenin blanc grafted onto different rootstock cultivars on a Dundee soil in the Montagu district (1978-1988).

\begin{tabular}{|c|c|c|c|c|c|c|c|}
\hline $\begin{array}{l}\text { ROOTSTOCK } \\
\text { CULTIVAR }\end{array}$ & $\begin{array}{l}\text { Yield } \\
(\mathrm{t} / \mathrm{ha})\end{array}$ & $\begin{array}{l}\text { Pruning Mass } \\
(\mathrm{t} / \mathrm{ha})\end{array}$ & $\begin{array}{l}\text { Yield: Cane } \\
\text { Mass Ratio }\end{array}$ & $\begin{array}{c}\text { Sugar } \\
\left({ }^{\circ} \mathrm{B}\right)\end{array}$ & $\begin{array}{c}\text { Total Titratable } \\
\text { Acidity }(\mathrm{g} / \mathrm{l})\end{array}$ & $\begin{array}{c}\text { Sugar: } \\
\text { Acid Ratio }\end{array}$ & $\mathrm{pH}$ \\
\hline Richter 99 (RY 13) & 28.41 & 2.50 & 11.36 & 19.4 & 6.7 & 2.88 & 3.30 \\
\hline C. Metallica & 27.71 & 2.68 & 10.34 & 20.6 & 6.8 & 3.04 & 3.31 \\
\hline Dog Ridge & 26.28 & 2.72 & 9.66 & 20.1 & 6.8 & 2.96 & 3.30 \\
\hline Ramsey & 25.21 & 2.66 & 9.48 & 19.9 & 6.7 & 2.97 & 3.28 \\
\hline $101-14 \mathrm{Mgt}$ (VORI) & 25.10 & 1.93 & 13.01 & 20.5 & 6.0 & 3.42 & 3.32 \\
\hline Richter 110 & 23.62 & 2.26 & 10.45 & 21.0 & 6.9 & 3.02 & 3.29 \\
\hline 143-B Mgt & 23.29 & 3.22 & 7.23 & 20.4 & 7.1 & 2.89 & 3.30 \\
\hline 101-14 Mgt (KWV) & 22.68 & 2.38 & 9.53 & 21.2 & 6.4 & 3.34 & 3.35 \\
\hline $3306^{\circ} \mathrm{C}$ & 22.41 & 2.00 & 11.21 & 20.1 & 6.8 & 2.96 & 3.29 \\
\hline Rup. du Lot & 21.08 & 2.47 & 8.53 & 20.2 & 6.7 & 3.02 & 3.32 \\
\hline Richter 99 (VORI) & 20.21 & 1.66 & 12.17 & 19.6 & 6.4 & 3.09 & 3.29 \\
\hline Jacquez & 20.18 & 2.04 & 9.89 & 20.0 & 6.8 & 2.94 & 3.30 \\
\hline Richter $99(2 / 2 / 10)$ & 17.99 & 1.49 & 12.07 & 20.5 & 5.8 & 3.54 & 3.33 \\
\hline Richter 99 (RY 30) & 17.20 & 1.55 & 11.10 & 20.1 & 6.0 & 3.37 & 3.30 \\
\hline De Waal & 16.54 & 1.84 & 8.99 & 20.1 & 7.0 & 2.89 & 3.31 \\
\hline $\operatorname{LSD}(\mathrm{P} \leq 0.05)$ & 3.36 & 0.44 & 2.20 & 0.8 & 0.4 & 0.25 & 0.07 \\
\hline
\end{tabular}




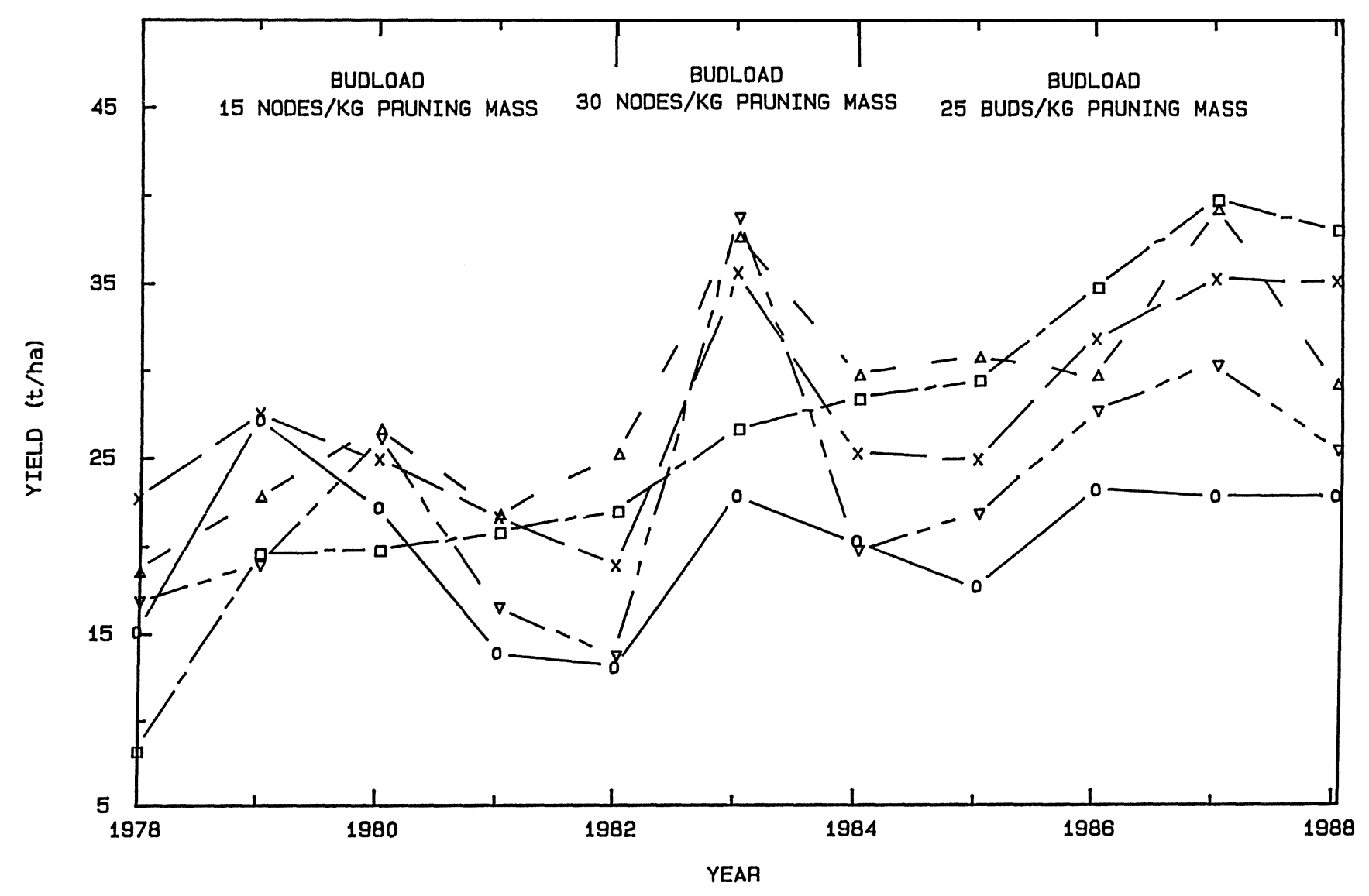

FIGURE 1

Yield of Chenin blanc grafted onto different rootstock cultivars on a Dundee soil in the Montagu district. 1978-1988. O Jacquez, $\square$ Dog Ridge, $\Delta 99$ Richter (RY 13), $\nabla 143-B$ Mgt., X Constantia Metallica.

all rootstocks greater than 12,6$)$, and it was therefore maintained at 25 nodes/kg pruning mass from 1984 onwards.

The mean yield of 99 Richter (Clone: RY 13) was significantly higher than the yields of the other 99 Richter clones and selections. The mean sugar content of the former graft combination was generally lower than that of all the other graft combinations, albeit not always significantly (Table 2), which could be the result of phenological differences as all the rootstocks were harvested on the same date.

Relative to the other rootstocks, Dog Ridge showed consistent improvement and stability in yield from the start of the trial. Conversely, relatively high yields were obtained with Jacquez at the start of the trial, but its yield was surpassed by that of other graft combinations in subsequent years. This decline occurred despite the absence of phylloxera nematodes in the soil and could be the consequence of overcropping early in the trial and/or nematode damage. No rootknot nematode species were found in the soil, and although the citrus nematode (Tylenchulus semipenetrans) was present in the soil samples, its populations were lower than those at which they affect the grapevine ( J Loubser - personal communication).

In the literature it is stated that the performance of 143-B Mgt and Constantia Metallica tends to decline in the long term (Orffer, 1966; Carstens, Burger \& Kriel, 1981; Archer, 1986). Despite a considerable fluctuation in the yield, however, particularly with $143-\mathrm{B} \mathrm{Mgt}$, no general decline in the performance of these two rootstocks was observed in this trial, which could be the consequence of improved plant material. Whether their relatively good performance will be maintained for the next 10 years is yet to be established.

Pruning mass: The mean pruning mass of 143-B Mgt was significantly higher than that of any other rootstock, while that of Dog Ridge, Constantia Metallica and Ramsey was more than 2,65 t/ha over the 11 years of the trial (Table 2). These graft combinations had significantly higher mean pruning masses than Jacquez, 101-14 Mgt (VORI selection), 3306 Couderc, De Waal and all the clones and selections of 99 Richter, with the exception of 99 Richter (Clone: RY 13).

The mean crop:pruning mass ratio of Chenin blanc grafted onto 143-B Mgt was significantly lower than that of all the other graft combinations, with the exception of De Waal and Rupestris du Lot (Table 2). This, associated with its high mean pruning mass, suggests that this graft combination was undercropped and that higher yields could possibly have been obtained by allocating more nodes per vine.

Similarly to the yield, the pruning masses of all the graft combinations improved from 1981 as the result of the improvement in irrigation in the subsequent years (Fig. 2).

Although the pruning masses of Dog Ridge, Ramsey and Constantia Metallica were relatively high, satisfactory yields were obtained with these graft combinations (Table 2). This suggests that the maintenance of a crop:cane mass ratio of 9 


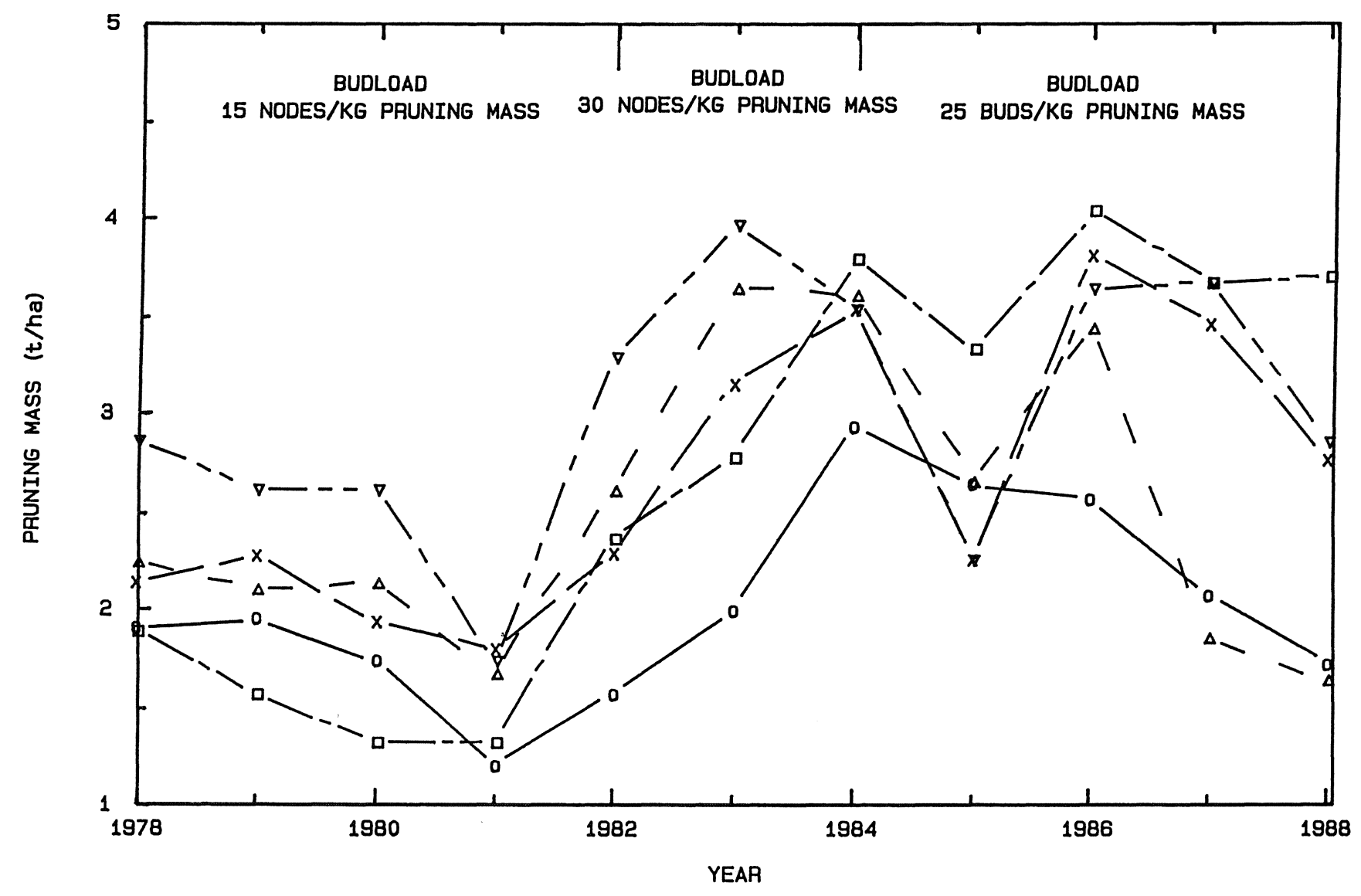

FIGURE 2

Cane mass of Chenin blanc grafted onto different rootstock cultivars on a Dundee soil in the Montagu district. 1978-1988. O Jacquez, $\square$ Dog Ridge, $\Delta 99$ Richter (RY 13), $7143-B$ Mgt., X Constantia Metallica.

to 10 is suitable for these graft combinations. This ratio is higher than that suggested by Zeeman (1978) for the Robertson area, but in this trial no detrimental effects on performance or on the composition of the grapes were discernable.

The improvement in plant material and improved cultivation techniques have resulted in excessive growth in certain areas and consequently a renewed interest in growth limiting rootstocks. Ideally such a rootstock should consistently produce relatively high yields associated with a high crop:cane mass ratio. In this trial moderate growth was obtained with Chenin blanc grafted onto 101-14 Mgt (VORI selection) and 3306 Couderc. The crop:cane mass ratio of the former graft combination was significantly higher than for the majority of the other rootstocks, and 101-14 Mgt produced consistently higher than average yields from 1979 to 1988 , with relatively high sugar concentrations, which suggests that this cultivar meets with the requirements of a growth limiting cultivar. The crop:cane mass ratio of 3306 Couderc was also relatively high, and its mean yield was comparable to that of 101-14 Mgt but tended to vary considerably in the later years of the trial. Its potential as a rootstock in areas of excessive growth, however, should not be overlooked.

The mean pruning mass of 99 Richter (Clone: Ry 13) was significantly higher than that of the other clones of 99 Richter, namely RY 30 and 2/2/10, and the VORI selection, which emphasises the importance of using the correct clonal material. Whether the same clone will perform similarly in other areas with respect to the other clones cannot, however, be deduced from these results.

\section{CONCLUSIONS}

The rootstock cultivars 99 Richter, Constantia Metallica, Dog Ridge, Ramsey and 101-14 Mgt appear to be well adapted to a Dundee soil in the Montagu district. Constantia Metallica and 143-B Mgt, however, have the repuation of deteriorating in the long term, and this aspect has to be clarified with the continuation of the trial over the next ten years.

The performance of the different clones of 99 Richter included in this trial differed markedly, both the yield and growth of clone RY 13 being consistently higher than those of the other clones of 99 Richter, which emphasises the importance of using the correct clonal material. Whether these differences are similar for all areas cannot be concluded from these results.

Since 101-14 Mgt consistently produced high yields with relatively low cane masses, this cultivar shows potential as a growth limiting rootstock.

The yield of Dog Ridge improved continually over the trial period and it was one of the highest producers in the later 
years of the trial; consequently it merits more attention despite its poor rooting ability.

\section{LITERATURE CITED}

AMBROSI, H., COETZEE, J.H.L., VAN NIEKERK, J. \& KRIEL, G.J. le R., 1966 Vergelyking van onderstokke in Suid-Afrika. Wynboer 414, 21-32.

ANONYMOUS, 1984. Wingerdboukundige eienskappe van onderstokke. Wynboer Tegnies, 7, 18-19.

ANONYMOUS, 1988. Statistieke van wingerdstokke soos op 30 November 1988. Legal Administration Division, KWV, P.O. Box 528, 7624 Suider Paarl, Rep. of South Africa.

ARCHER, E., 1986. Rootstocks for Winegrapes: Constantia Metallica. VORI 198 Private Bag X5026, 7600 Stellenbosch, Rep. of South Africa.

BEUKMAN, E.F., 1976. Kommentaar oor tendense en verskynsels soos afgelei uit wingerdstatistieke op 15 Oktober 1974. Supplement to Wynboer 533.

CARSTENS, W.J., BURGER, J.D. \& KRIEL, G.J. le R., 1981. Cultivarbeleid, cultivareienskappe en plantverbetering. In: BURGER, J. \& DEIST, J. (eds.) Wingerdbou in Suid-Afrika. VORI, Private Bag X5026, 7600 Stellenbosch, Rep. of South Africa. pp. 62-119.

DE KLERK, C.A., 1970. Biologie van die wingerdfilloksera Phylloxera vitifoliae Fitch. (Homoptera: Phyloxeridae in Suid-Afrika. M.Sc. Thesis, University of Stellenbosch, 7600 Stellenbosch, Republic of South Africa.

DE KLERK, C.A., 1978. Morphology and taxonomy of the South African species of the genus Margarodes (Hemiptera: Margarodidae), with detailed studies on the biology of two vine infesting species. Ph.D. dissertation, University of Stellenbosch, 7600 Stellenbosch, Republic of South Africa.

KRIEL, G.J. le R., 1985. Die keuse van onderstokke. Wynboer Tegnies 12, 11-15.
LE ROUX, E.G., 1974. 'n Klimaatsindeling van Suidwes-Kaaplandse wynbougebiede. M.Sc. Thesis, University of Stellenbosch, 7600 Stellenbosch, Republic of South Africa.

LOUBSER, J.T., 1985. A modified sieving-sedimentation method for extracting nematodes from soil. Hort. Sci. 3, 23-25.

LOUBSER, J.T., FERREIRA, J.H.S. \& DE KLERK, C.A., 1987. Weerstandbiedenheid van wingerdonderstokke teen knop-wortelaalwurms, filloksera, kroongal en phytophthora. Wynboer Tegnies 19, 4-6.

MACVICAR, C.N. \& Soil Survey Staff, 1977. Soil classification. A binomial system for South Africa. Dept. Agric. Tech. Services Scientific Pamphlet 390, Government Printer, 0001 Pretoria, Rep. of South Africa.

MARAIS, P.G., 1978. Occurrence and control of Phytophthora cinnamomi in South African vineyards. Proc. S. Afr. Soc. Enol. Vitic. 1978, Oct. 3/4, 4-27.

MARAIS, P.G., 1983. Phytophthora cinnamomi root rot of grapevines in South Africa Ph.D. dissertation, University of Stellenbosch, 7600 Stellenbosch, Republic of South Africa.

ORFFER, C.J., 1966. 143-B stel teleur. Wynboer, 414, 9-11.

PONGRACZ, D.P., 1969. 'n Opname van wyndruifwingerde en onderstokmoederplantasies in Wes-Kaapland met spesiale verwysing na die gedrag van verskillende onderstoksoorte. Wynboer 454, 1-16.

PONGRACZ, D.P., 1983. Rootstocks for grapevines. David Philip Publisher (Pty) Ltd, 7700 Claremont, Rep. of South Africa. pp. 76-77, 83-85.

WINKLER, A.J., COOK, J.A., KLIEWER, W.M. \& LIDER, L.A., 1974. Genera Viticulture. Univ. of Calif. Press, Berkeley.

ZEEMAN, A.S., 1978. Effect of rootstocks on performance of Chenin blanc under various environmental conditions. Proc. S. Afr. Soc. Enol. Vitic., Oct. 3/4, 71-85. 